\title{
Model of Cooperative Script Application in My Ideals Theme to Improve Student Learning Outcomes in SDN 101775 Sampali
}

\author{
Daitin Tarigan $^{1 *}$, Ammi Al-Habiby Telaumbanua ${ }^{2}$, \\ Try Wahyu Purnomo ${ }^{3}$, Sri Mustika Aulia ${ }^{4}$ \\ ${ }^{1-4)}$ Faculty of Education - Universitas Negeri Medan, Indonesia \\ *daitintarigan@gmail.com
}

\begin{abstract}
This research is motivated by the low learning outcomes of fourth grade students of SD Negeri 101775 Sampali- Indonesia, teacher skills in learning are still teacher-centered, and teachers do not provide opportunities to ask students questions and do not involve students in the learning process. After the first cycle, there was an increase in which 10 students received $\leq 70$ or incomplete $(41.67 \%)$ and those who received $\geq$ $70 \%$ or 14 completed $(58.33 \%)$. This shows that the value of student learning outcomes in the first cycle has not yet reached the level of learning success (classical completeness) because it is still below $85 \%$. Based on the research results of the implementation of the second cycle, it can be seen that 22 people $(91.67 \%)$ have finished, and 2 people $(8.33 \%)$ have not yet finished. The classical completeness level reaches $92 \%$ which indicates that classical learning outcomes have been completed $(\geq 85 \%)$.
\end{abstract}

Keywords: Learning Outcomes, Cooperative Script

\section{Introduction}

Learning outcomes are a description of how students understand the material delivered by the teacher. Learning outcomes are outputs in the form of numbers or letters obtained by students after receiving learning material through a test or exam given by the teacher. From these learning outcomes teachers can receive information on how far students understand the material being studied. The success of students in achieving learning outcomes in each student is different. The factors that influence student success in achieving learning outcomes are grouped into two namely internal factors and external factors. Internal factors are all factors that originate from within students, including the level of intelligence, interest, motivation and so on. While external factors are all factors from outside students, including family environment, community, relationships, learning facilities, family socio-economic conditions and so on [1]. Thematic learning is a learning approach that integrates various competencies from various subjects into various themes. The integration is carried out in various ways, namely the integration of attitudes, skills and knowledge in the learning process and the integration of various related basic concepts [2]. The theme knits the meaning of various basic concepts so that students do not learn the basic concepts partially. Learning gives full meaning to students as reflected in the various themes available. Integrative thematic learning, the theme chosen must be related to nature and human life. From a psychological point of view, students have not been able to think abstractly to understand separate subject content. 
In the 2013 curriculum there is the term Core Competencies. Core Competence is a categorical description of SKL in the aspects of attitudes, knowledge, and skills that students must learn for levels of school, class and subjects. These competencies are designed in four interrelated groups, namely with regard to religious attitudes (Core Competencies 1), social attitudes (Core Competencies 2), knowledge (Core Competencies 3), and skills (Core Competencies 4). Learning outcomes are often used as a measure to find out how far someone masters the material that has been taught. Learning is done to try to change behavior in individuals who learn. Changes in behavior that is the acquisition of learning outcomes. Based on observational results conducted by researchers at SD Negeri 101775 Sampali, Indonesia in class IV term 1, reports were obtained that student learning outcomes in odd semester exams were still low, from 24 students to only 14 students or around $53.8 \%$ who managed to study thoroughly at for the KKM value. While there are 10 students or $46.2 \%$ of the total students whose learning scores have not been completed below the the standard value of 70 . That is because the students have not fully explored the material and the teacher is still using conventional methods in the learning process while the teachers should implement the 2013 curriculum using a scientific approach, which is learning that prioritizes students' experiences through observation (reading, listening, listening, seeing, asking and communicating) In addition, learning activities are still centered on the teacher and the teacher does not involve students in the learning process, so children tend to be passive in following the learning process, which is seen from reluctance to ask questions and express opinions. Based on this information, a learning strategy is needed in learning. Learning strategy is an art and science to bring learning in such a way that the goals set can be achieved efficiently and effectively. Learning strategies can be outlined through innovative learning models. The methods chosen in compiling the learning model include the nature, scope and sequence of activities that can provide learning experiences for students. The learning model is not only limited to procedures and activities, but also includes teaching material or teaching packages.

Efforts in realizing the objectives to be achieved, namely improving student learning outcomes in learning needed an effective learning model strategy by presenting a set of facts that occur in the surrounding environment, students must do something, know and solve problems related to the problems they experience. Based on this information, a teacher needs to apply a model that directs students to play an active role and explore the potential that exists in themselves, so students are able to develop certain skills such as skills in problem solving, decision making skills, skills in analyzing data, thinking logical and systematic. One learning model that involves the ability of students to work together to solve problems in learning and to build concepts or principles with their own abilities that integrate skills and knowledge that has been previously understood, that is by applying the Cooperative Script model.

\section{Research Method}

This research can be classified into types of action research. In this study, because the subject to be studied was a group of students in the class, the type of research used was classroom action research [1,3], classroom action research is defined as a form of research that is reflective by doing certain actions in order to improve and enhance teaching practices in the classroom more professionally. The study was conducted at SDN 101775 Sampali, Deli Serdang Regency. When the research was carried out at the beginning of the even semester of the 2018/2019 school year for three months from March to May 2019 with IVSD as the subject of grade IV students of SDN 101775 Sampali in the 2018/2019 academic year totaling 
24 people, with details of 14 men and 10 women. The average age of students who are the subjects in this study is between 11-12 years.

The object of the research is the science lesson with basic competencies to create a life cycle scheme in the surrounding environment and the slogan of its conservation efforts. roadly speaking, there are stages that will be passed in classroom action research, namely: (1) planning, (2) implementation, (3) observation, and (4) reflection. Classroom action research in this study will be carried out two cycles based on the Kemmis and Taggart models [2,4]. The research was carried out for two cycles, each cycle consisting of planning, implementation, observation and reflection [5]. The implementation of this research begins with initial reflection, which includes problem identification, problem analysis, problem formulation and action formulation [6]. After that the researchers conducted the planning, implementation, observation and reflection. This research was conducted in the form of collaboration between researchers and class teachers. In this case before researchers appear in front of students to teach, researchers first see the appearance of class teachers in teaching $[6,7]$.

\section{Results and Discussion}

In this study there were two objects observed, namely students and teachers / researchers. Observation of students is done on student activity in the learning process. Observations of teachers or researchers carried out to determine the performance of the teacher or researcher during the learning process

Researchers carry out research starting from giving Pre Test to all students by giving 15 multiple choice questions. The initial test (pre-test) given to students before carrying out action planning aims to find out the student's initial ability and also to find out the depictions of difficulties experienced by students in solving questions on the subject of "efforts to preserve the surrounding environment" with the evaluation criteria ie the scores obtained are divided with a maximum score times 100 .

Seen from the average grade only reached 43.9 which is still relatively low. Of the 24 students, none had a very good $(0 \%)$ and good $(8.3 \%)$ criterion. There were $3(12.5 \%)$ students who achieved sufficient criteria, and 19 (79.17\%) students who lacked the criteria. Completed students are as many as 4 students and as many as 18 students are incomplete. Of the 24 students, only 5 students completed, and 19 students did not complete the pretest.

The pre-test scores of 24 students before learning on science subjects on the theme of my ideals showed that the lowest score obtained by students was a score of 20 and the highest of 80 . Students who achieved grades $<70$ or incomplete were 19 students $(79.17 \%)$ and students who reached $\geq 70$ or complete as many as 5 students $(20.83 \%)$. The average value of student learning is 43.9 .

Classical completeness reached mastery of $20.83 \%$. This shows the pre-test scores of students still have a success rate of learning (classical completeness) under $85 \%$ and these students have not yet thoroughly studied the material in an effort to preserve the environment in science subjects. The first cycle post test shown in the table above shows that the level of students' mastery of the material preserving the surrounding environment began to increase. Seen from the average value of the class which reached 60.30 which is quite high. Of the 24 students, none had a very good criterion (0\%). There were $7(29 \%)$ students who achieved good criteria, $3(13 \%)$ students who had sufficient criteria, $14(58 \%)$ students in the criteria were very less. Completed students are as many as 10 students and as many as 14 students are incomplete. from 24 students, 10 students who completed, and 14 students did not complete the post test cycle I. 
The percentage of students' mastery learning in the first cycle was $41.67 \%$. It can not be said to be successful because it does not meet the criteria for success indicators that have been applied, namely student learning completeness of at least $85 \%$. A class is said to be complete learning if the class has $85 \%$ of students who have achieved a minimum completeness criteria score of 70

In the first cycle meeting 1 teacher activities that get good categories include explaining the learning objectives, giving problems / questions clearly, motivating students to solve problems, guiding students to present the results of their partner's discussion, respecting students' questions / opinions and evaluating the problem solving process.

While for the sufficient category is explaining apperception, explaining the learning steps, guiding students to form groups of pairs, directing students to solve problems, giving students the opportunity to ask questions, assessing what they are, and summarizing learning outcomes.

Whereas for cycle I meeting 2 which got a good category of explaining the learning objectives, guiding students to form groups of pairs, giving questions / problems clearly, guiding students to, motivating students in the problem solving process, guiding students to present the results of discussions, respecting questions / opinions students and analyze learning outcomes.

For the sufficient category that is doing apperception, explaining the steps of learning, giving students the opportunity to ask questions, guiding the course of class discussion, and giving an assessment as it is

Based on the observation sheet of the teaching activities of the teachers above it can be concluded that the teaching activities of the teachers are classified as lacking because the value of the observation results was 61.66 at meeting 1 and 66.66 at meeting 2 .

Cooperative Script Learning Model, it can be seen that the number of students who completed as many as 12 students and an average value of 60.30. In the first cycle, the results obtained by students are better or have increased from the results of the pretest which at the time of the pretest students' mastery learning classically by $20 \%$ with the number of students who completed as many as 5 students and an average value of 43.90. Although there was an increase in the first cycle, it has not been said to be successful because it has not met the criteria for success indicators that have been set namely classical learning completeness of at least $85 \%$ of students who have achieved a minimum completeness criterion value of 70 . the level of student mastery of the material to preserve efforts environment improved from the previous posttest I It can be seen from the average grade of the class which reaches 80 which is classified as high. Of the 24 students, there were $21(88 \%)$ students who achieved good criteria, $1(4 \%)$ students who had sufficient criteria, and $2(8 \%)$ students in poor criteria. Completed students were 22 students and those who did not complete were 2 students.

In the activities of the second cycle teacher meeting 1 which got a very good category include giving apperception, explaining the learning steps. As for the good category of explaining learning objectives, guiding students to form groups in pairs, giving students the opportunity to ask questions, motivating students, guiding students to present the results of discussions, respecting questions and opinions of students, giving assessments to students and assigning assignments to students.

Whereas for the second cycle meeting 2 which received very good categories including giving apperception, explaining the learning objectives, explaining the learning steps, giving questions to students clearly, giving students the opportunity to ask questions, respecting students' opinions, evaluating learning.

As for the good category of guiding students to form groups in pairs, directing students to solve problems, providing motivation to students, giving students the opportunity to ask 
questions, guiding students in presentations, guiding students to discussions, and assigning assignments to students.

Based on the observation sheet of the teaching activities of the teacher above it can be concluded that the teaching activities of the teacher are classified as good because the value of the observation results is 86.66 at the 1 st meeting and 90 at the 2 nd meeting. Based on the results of research that has been done, researchers obtain student learning outcomes on the initial ability test (Pre-test) that is students who complete learning as many as 5 students $(21.83 \%)$ and as many as 19 students $(79.17 \%)$ with an average grade average 43.9 (Very Poor). Based on the results of the pre-test, the researchers made an effort to improve student learning outcomes by using the Cooperative Script Learning Model. After the completion of the first cycle of action and the researcher gave the post test questions to the students, the results obtained a total of 10 students $(41.67 \%)$ and 14 students $(58.33 \%)$ who did not complete with an increasing classical average score. to 60 (Less).

Based on the results of the post test in cycle I, the researcher continues to strive to improve student learning outcomes by using the Cooperative Script Learning Model in cycle II. After the second cycle of action was completed, the researchers gave a post test cycle II, the learning outcomes significantly increased by obtaining the number of students who completed as many as 22 students $(91.67 \%)$ and those who did not complete 2 students $(8.33 \%)$ with an average value which is increasing again until it reaches 80 (Good). The results of this study are in line with relevant previous studies such Elliot (2008), Elisa, and Wrastari (2013), and Hwang, Yoon-Suk (2010).

\section{Conclusion}

Based on the results of research, analysis and reflection of each cycle, it can be concluded that the use of the Cooperative Manuscript model can improve student learning outcomes in the Theme of My Dream Sub-them Trying to Achieve Goals. Improved student learning outcomes can be evidenced from the average value and success of student learning classically based on the results of the pretest, post-test cycle I and post-test cycle II.

1) Before being given an action from the results of the pre-test obtained an average ability of students' initial knowledge of 43.9. After the first cycle of action from the results of the post-test I obtained student learning outcomes increased to an average of 60 . Furthermore, from the results of the post-test cycle II obtained student learning outcomes increased to an average of 80 .

2) The percentage of students' success classically before being given an action (pre-test) was $21 \%$. In the first cycle the percentage of students' success classically from the results of the post-test I increased to $41.67 \%$. After making improvements in the second cycle, from the results of the post-test II the percentage of students' success classically increased to $91.67 \%$.

3) Researchers' activities during the learning process have been classified as very good and the aspects observed based on the existing observation sheet format have all been carried out.

\section{References}

[1] Sugiyono, (2008), Metode Penelitian Pendidikan;Pendekatan Kuantitatif, Kualitatif dan $R \& D$, Bandung: Alfabeta.

[2] Arikunto S. Suhardjono and Supardi. (2010), Penelitian Tindakan Kelas. Jakarta: Bumi. 
[3] Dewi, Rosmala. (2015), Profesionalisasi Guru Melalui Penelitian Tindakan Kelas. Medan: Pasca Sarjana Unimed..

[4] Fanu, J.L. (2006), Deteksi Dini Masalah-Masalah Psikologi Anak. Yogyakarta: Think.

[5] Yus Anita. (2012), Penilaian Perkembangan Belajar Anak TK, Penerbit :Kencana.

[6] Ngalim Purwanto. (2002), Ilmu Pendidikan. Bandung: Remadja Rosda Karya.

[7] Muslimin Ibrahim. (2000), Pembelajaran Kooperatif. Surabaya: University.

[8] Elliot, S. (2008), The Effect of Teachers' Attitude Toward Inclusion on the Practice and Success Levels of Children with and without Disabilities in Physical Education. International Journal of Special Education.

[7] Elisa, S \& Wrastari, AT. (2013), Sikap Guru Terhadap Pendidikan Inklusi Ditinjau Dari Faktor Pembentuk Sikap. Fakultas Psikologi Universitas Airlangga Surabaya: Jurnal Psikologi Perkembangan Dan Pendidikan, 2 (1).

[8] Hwang, Yoon-Suk. (2010), Attitudes towards inclusion: gaps between belief and practice. International Journal of Special Education. 